$\left[\begin{array}{c}\text { J.M.J., Vol. 5, No. } 3 \text { ] } \\ \text { June, } 195 \%\end{array}\right.$

\title{
ON THE AFFINITY OF A FEW STRAINS OF ENCEPHALITIS \\ VIRUS TO VARIOUS ORGANS OF MICE, ESPECIALLY \\ BRAIN AND BLOOD, COMPARISONS BEING MADE WITH THAT OF NEGISHI STRAIN
}

\author{
NOBUO HIRONAKA
}

\author{
National Institute of Health, Tokyo, Japan
}

Since the epidemic outbreaks of encephalitis in St. Louis and Kansas City, U.S.A. and in Tokyo, Japan, numerous research works have been reported by American and Japanese investigators on the isolation of causative virus or on its immunological and epidemiological studies.

However, those questions relative to the route of infection or the affinity of the causative virus to various organs have not yet been explained experimentally in a satisfactory manner. The above is considered due to the facts that the epidemic is relatively sporadic, that family infection is quite rare and that there are a number of inapparent infections with serologically positive findings. Not all of the individuals infected will develop the symptoms, thus necessitating one to consider the factors inhibiting actual occurrence of the disease on both virus and host sides. The mosquito transmission theory of encephalitis virus presented by $\mathrm{T}$. Mitamura et $\mathrm{al}^{(1)}$ and W. McD. Hammon \& W. C. Reeves et $\mathrm{al}^{(2)(3)}$ has gained general acceptance nowadays as the most reliable theory, through a number of researches made both in laboratories and in the field. But even this theory has a weak point in explaining the reservoirs of encephalitis virus present in nature. The same remarks can be made on the nasal instillation theory, which was presented by $\mathrm{R}$. Kawamura et $\mathrm{al}^{(4)}$. Process and mechanism of the infection exercised by the virus and the host, therefore, are the most essential aspects for evaluating such theory. Such a study, however, is extremely difficult, because of the involvement of too many factors which need a considerable length of time to dissolve. But as the first step into such a field, experiments were carried out to know the affinity of virus to various organs of experimentally infected mice. Numerous experiments have already been reported on this subject but those made on Japanese B encephalitis virus in comparison with several other strains of similar nature are extremely rare. There are two 
principal attitudes to this problem. Some investigators are inclined to explain it by the multiplication of virus in organs, except central nervous system, in the initial days ${ }^{(5)(6)}$, and others are against them ${ }^{(7) \cdot 8)}$.

K. Ando and his co-workers have isolated two strains of encephilitis virus, Negishi and $K-13$, from the patients occurred in Tokyo during the epidemic of Japanese B encephalitis in the summer of 1948. Serological differentiation of these two strains was not practicable ${ }^{(9)}$. Comparing the affinity of Negishi strain to various organs in mice with that of Nakayama (Japanese B encephalitis virus) and St. Louis encephalitis virus ${ }^{(10)}$, Negishi strain was found to infect mice by oral administration more easily than Japanese B encephalitis virus or St. Louis encephalitis virus. Comparisons of biological characters, especially their affinity to blood and central nervous system, were made with Russian spring summer encephalitis virus (western type). At the same time, comparisons were made with Nakayama and St. Louis encephalitis viruses, which have been passed through many brains of mouse, and also with those viruses which have not been passed through so many mouse brains.

The experiments described above are one of the measures to clarify the course of infection on the basis of affinity to various organs of mice, which is not yet determined to lie whether on the side of virus or host.

Reported herein are the results obtained from those experiments described above. The results were not of full satisfaction, but some biological differences existing among encephalitis viruses were clarified by them.

\section{MATERIALS AND METHODS}

\section{Materials}

\section{a. Viruses}

i. Russian spring summer encephalitis virus (western type). Obtained from Dr. M. Kitaoka.

ii. Negishi strain. Isolated from the material of the encephalitis case during the summer 1948.

iii. Komagome strain (Japanese B encephalitis virus). Same as above.

iv. K-11 strain. Same as above.

v. Fujimaki strain. Isolated from the material of Japanese B encephalitis case during the summer 1950 in our laboratory.

vi. Oikawa strain. Same as above. 
vii. St. Louis encephalitis virus. Received from the 406th MGL, U.S. Army.

viii. Nakayama strain. Isolated during the summer 1935 by Dr. S.

Kasahara and received from the 406th MGL, U.S. Army in 1949.

b. Mice

White mice weighing $13-15 \mathrm{~g}$ were used in this study. Virus titrations were carried out by intracerebral inoculation of mice weighing about $8 \mathrm{~g}$. $\mathrm{LD}_{50}$ titers indicated in the protocols were calculated by the method of Reed and Muench(11), the original blood being regarded as a zero dilution, and 10 per cent suspensions as $10^{-1}$ dilutions.

c. Rabbits

Rabbits weighing approximately $3,000 \mathrm{~g}$ were used in the experiment of intratesticular inoculation.

d. Diluent

One per cent yolk buffered saline solution was used ${ }^{(12)}$.

2. Methods

a. Intranasal instillation

A virus suspension was dropped in a dose of $0.05 \mathrm{cc}$ into the nasal cavity of mouse weighing $13-15 \mathrm{~g}$ without anesthetizing the animal ${ }^{(13)}$.

b. Intravenous injection

Desired amount of a dilution of virus was injected into the tail vein of mouse.

c. Intratesticular inoculation

Required concentration of virus was inoculated in a dose of approximately $0.03 \mathrm{cc}$ into each testicle of a mouse weighing $13-15 \mathrm{~g}$ under ether anesthesia. The anesthesia also facilitated inoculation by causing the testicles to descend from their intraabdominal position. For rabbits, after fixing, a virus suspension was inoculated in a dose of $0.5 \mathrm{cc}$ into the testicles without giving anesthesia.

\section{EXPERIMENTS}

1. Intranasal instillation

In each time, 2 mice were sacrificed by ether anesthesia, and mainly brain and heart blood, when necessary other organs too, were taken out and the amount of virus contained was titrated. More than 2 mice were sacrificed occasionaly to know the presence of virus in brain or blood in an early period after the inoculation. Results obtained are shown in 
Table 1 to 7 . With Nakayama strain, the virus of infected mice was proved first in brain, then in blood at the terminal stage. Amount of the virus present in blood was very small. These finding are in conformity to those described by K. Kimura ${ }^{(14)}$. Results with St. Louis encephalitis virus are shown in Table 1 . There was not any appreciable biological

Table 1

Distribution of St. Louis Encephalitis Virus in Susceptible Mice Following Intranasal Instillation. $(10 \mathrm{x}, 0.05 \mathrm{cc}$.

\begin{tabular}{|c|c|c|c|c|c|c|c|}
\hline \multirow{4}{*}{ Organs } & \multicolumn{7}{|c|}{ Days Elapsed After Inoculation. } \\
\hline & 1 Day & 2 Days & 3 Days & 4 Days & 5 Days & 6 Days & 7 Days \\
\hline & \multicolumn{7}{|c|}{ Mouse No. } \\
\hline & 12 & 3 & 5 & 7 & 9 & 10 & 11 \\
\hline Brain & $0 / 5 \quad \% / 5$ & $0 / 5 \quad 4 / 5$ & $5 / 5 \quad 5 / 5$ & $5 / 5 \quad 5 / 5$ & 7.56 & 7.5 & 7.33 \\
\hline Blood & $0 / 5 \quad 0 / 5$ & $0 / 5 \quad \% / 5$ & $0 / 5 \quad \% / 5$ & $0 / 5 \quad 0 / 5$ & - & - & 0.67 \\
\hline Spleen & $0 / 5 \quad 0 / 5$ & $0 / 5 \quad 0 / 4$ & $\begin{array}{ll}? & 0_{/ 3}^{\prime}\end{array}$ & $\begin{array}{ll}? & 0_{/ 5}\end{array}$ & - & 2.83 & 3.0 \\
\hline $\begin{array}{l}\text { Gl. Sub- } \\
\text { mandib. }\end{array}$ & $0 / 5 \quad 0 / 5$ & $? \quad 0 / 4$ & $0 / 5 \quad 0 / 5$ & $0 / 5 \quad 0 / 5$ & & & 0.33 \\
\hline Kidneys & $0 / 5 \quad 0 / 5$ & $0 / 5 \quad 0 / 5$ & $0 / 4 \quad 0 / 5$ & $0_{/ 5} \quad 0 / 5$ & & & 1.0 \\
\hline Adrenals & $0 / 3 \quad 0 / 5$ & $0 / 5 \quad 0 / 4$ & $0 / 4 \quad 0 / 5$ & $0 / 5 \quad 0 / 5$ & 3.33 & 5.0 & 5.5 \\
\hline $\begin{array}{l}\text { Ly. Gl. } \\
\text { Mesent. }\end{array}$ & $0 / 5 \quad \% / 5$ & $0 / 4 \quad \% / 4$ & $\%$ ? & $0 / 5 \quad 0 / 4$ & & & 3.5 \\
\hline Liver & $0 / 5 \quad \% / 4$ & $0 / 3 \quad \% / 5$ & $0 / 5 \quad 0 / 5$ & $0 / 5 \quad 0 / 4$ & & & 1.0 \\
\hline Large Intest & $0 / 3 \quad 0 / 5$ & $0 / 2 \quad 0 / 5$ & $0 / 1 \quad ?$ & $? \quad 0 / 2$ & - & 1.5 & 1.0 \\
\hline
\end{tabular}

All figures indicate the logarithm of $\mathrm{LD}_{50}$ endpoint dilution.

Dashes indicates "no virus detected".

Blankes indicate "not tested".

?: indicates the $\mathrm{LD}_{50}$ of the virus was not obtainable due to accident.

Tr: indicates some of the four mice inoculated with the undiluted blood died.

$>$ : indicates the titer of virus in higher than.

$<$ : indicates the titer of virus is lower than.

$=$ : indicates the titer of virus is equal to.

Numerators indicate the number of mice infected.

Denominators indicate the number of mice used.

difference between Nakayama and St. Louis strains. In this experiment, specifically, various organs of mice were examined, because L. T. Webster has reported that St. Louis encephalitis virus multiplies in the spleen of mouse $^{\left(1^{3}\right)}$. This virus was found first in brain and later in other organs. 
Moreover, the blood titer of the virus was very low, and as R. Kobayashi ${ }^{16)}$ and M. Takenouchi ${ }^{(17)}$ described, there was no strong evidence to show the multiplication of the virus in the spleen of mouse.

Results obtained with freshly isolated strains of Japanese B encephalitis virus, which have not been passed through many mouse brains, are shown in Table 3 to 5 . At first, experiments were made with $\mathrm{K}-11$ strain (12th mouse brain passage). In one of the mice examined, the virus was present in the blood $\left(\mathrm{LD}_{\tilde{5} 0}=\geqq 1.5\right.$ ), but not in the brain on the 3rd day, thus the same experiment was made with the virus of the 13th mouse brain passage. Contrary to the findings obtained with Nakayama and St. Louis encephalitis viruses, the results obtained showed that the virus was present, though small in amount, in blood earlier than it appeared in brain (Table 2). Similar experiments were carried out with Komagome

Table 2

Distribution of Jap. B Encephalitis Virus (K-11 Strain 13th Pass.) in Susceptible Mice Following Intranasal Instillation.

(10 x. 0.05 ca.)

i.c. $\mathrm{LD}_{50}=6.5$

\begin{tabular}{|c|c|c|c|c|c|c|c|c|c|c|c|c|c|c|c|c|}
\hline \multirow{4}{*}{ Organs } & \multicolumn{16}{|c|}{ Days Elapsed After Inoculation. } \\
\hline & $1 \mathrm{I}$ & bay & $2 \mathrm{I}$ & ays & $3 \mathrm{D}$ & Days & & Days & & Days & $6 \mathrm{Da}$ & & & Days & $8 \mathrm{Di}$ & ays \\
\hline & \multicolumn{16}{|c|}{ Mouse No. } \\
\hline & 1 & 2 & 3 & 4 & 5 & 6 & 7 & 8 & 9 & 10 & 11 & 12 & 13 & 14 & 15 & 16 \\
\hline Brain & - & - & - & - & 2.67 & $7-$ & & -4.0 & $\geqslant 6$ & 6.54 .0 & $\geqslant 6.33$ & 6.0 & ? & $?$ & Ca4.67 & $\mathrm{Ca} 7.5$ \\
\hline Blood & - & - & & $\operatorname{Tr}$ & 0.77 & $7-$ & & r 0.62 & - & -- & - & $\operatorname{Tr}$ & - & - & - & - \\
\hline
\end{tabular}

All figures indicate the logarithm of $\mathrm{LD}_{50}$ endpoint dilution.

Dashes indicates " no virus detected".

Blankes indicate " not tested".

?: indicates the $L D_{50}$ of the virus was not obtainable due to accident.

Tr: indicates some of the four mice inoculated with the undiluted blood died.

$>$ : indicates the titer of virus is higher than.

$<$ : indicates the titer of virus is lower than.

$=$ : indicates the titer of virus is equal to.

Numerators indicate the number of mice infected.

Denominators indicate the number of mice used.

strains of the 6 th and 7 th mouse brain passage and the results obtained were the same. Only the results of the $6 \mathrm{~h}$ mouse brain passage strain are as shown in Table 3 . Next, the same experiments were made 
Table 3

Distribution of Jap. B Encephalitis Virus (Komagome Strain 6th Pass.) in Susceptible Mice Following Intranasal Instillation.

$$
(10 \mathrm{x}, 0.05 \mathrm{cc})
$$

i. c. $\mathrm{LD}_{50}=7.5$

\begin{tabular}{|c|c|c|c|c|c|c|c|c|c|c|c|c|}
\hline \multirow{4}{*}{ Organs } & \multicolumn{12}{|c|}{ Days Elapsed After Inoculation. } \\
\hline & \multicolumn{2}{|c|}{1 Day } & \multicolumn{2}{|c|}{2 Days } & \multicolumn{2}{|c|}{3 Days } & \multicolumn{2}{|c|}{4 Days } & \multicolumn{2}{|c|}{5 Days } & \multicolumn{2}{|c|}{6 Days } \\
\hline & \multicolumn{12}{|c|}{ Mouse No. } \\
\hline & 1 & 2 & 3 & 4 & 5 & 6 & 7 & 8 & 9 & 10 & 11 & 12 \\
\hline Brain & - & - & - & - & Ca3.33 & $\mathrm{Ca} 2.67$ & - & 2.0 & Ca5.33 & $\supseteqq 5.5$ & $\mathrm{Ca} 8.0$ & $\mathrm{Ca} 6.0$ \\
\hline Blood & - & - & 0.5 & $\operatorname{Tr}$ & $\supseteqq 1.5$ & Ca1.0 & - & - & - & 一 & - & - \\
\hline Spleen & - & - & - & - & - & 一 & - & - & 0.67 & 0.67 & 0.67 & - \\
\hline Liver & - & & - & & & - & - & & & - & - & \\
\hline Testicle & & - & & - & - & & & - & - & & & - \\
\hline
\end{tabular}

All figures indicate the logarithm of $L D_{\varepsilon_{0}}$ endpoint dilution.

Dashes indicates " no virus detected".

Blankes indicate " not tested".

?: indicates the $\mathrm{LD}_{50}$ of the virus was not obtainable due to accident.

Tr: indicates some of the four mice inoculated with the undiluted blood died.

$>$ : indicates the titer of virus is higher than.

$<$ : indicates the titer of virus is lower than.

$=$ : indicates the titer of virus is equal to.

Numerators indicate the number of mice infected.

Denominators indicate the number of mice used.

with Fujimaki strain of the 3rd mouse brain passage, which was isolated from the patient of different epidemic. The results showed that trace of the virus was proved present in blood of one mouse out of 4 examined (Table 4).

Table 4

Distribution of Jap. B Encephalitis Virus (Fujimaki Strain, 3rd Pass.) in Susceptible Mice Following Intranasal Instillation.

(50 x, 0.05 cc.)

i. c. $\mathrm{LD}_{50}=8.5$

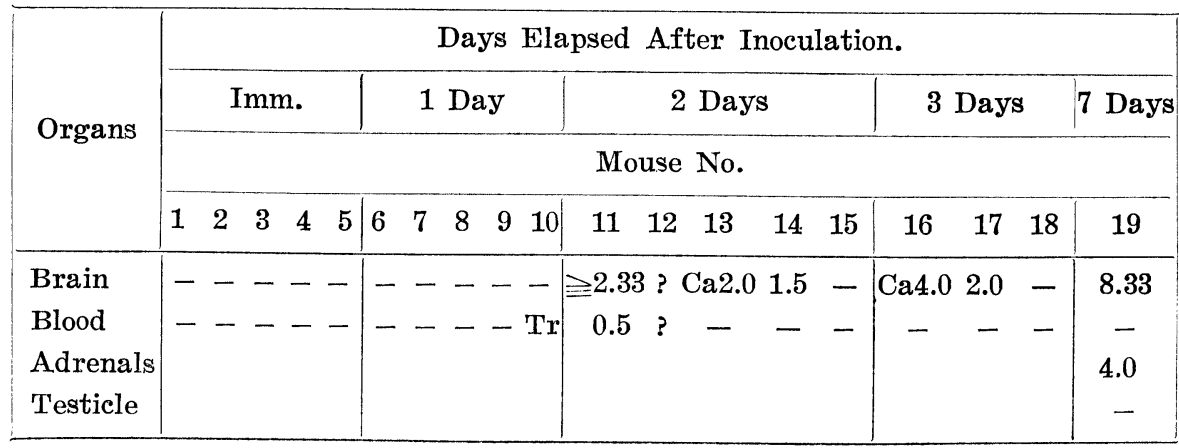


All figures indicate the logarithm of $\mathrm{LD}_{50}$ endpoint dilution.

Dashes indicates " no virus detected".

Blankes indicate " not tested".

?: indicates the $L D_{50}$ of the virus was not obtainable due to accident.

Tr: indicates some of the four mice inoculated with the undiluted blood died.

$>$ : indicates the titer of virus is higher than.

$<$ : indicates the titer of virus is lower than.

$=$ : indicates the titer of virus is equal to.

Numerator indicate the number of mice infected.

Denominatores indicate the numcer of mice used.

The results with Negishi strain are shown in Table 5. This virus appeared first in brain and then, being transmitted by blood stream, remained in various organs.

Table 5

Distribution of Negishi Encephalitis Virus in Susceptible Mice Following Intranasal Instillation. $(10 \mathrm{x}, 0.05 \mathrm{cc}$.

i. c. $L D_{50}=8.5$

\begin{tabular}{|c|c|c|c|c|c|c|c|c|c|c|c|}
\hline \multirow{4}{*}{ Organs } & \multicolumn{11}{|c|}{ Days Elaped After Inoculation. } \\
\hline & \multicolumn{2}{|c|}{1 Day 2 Days } & \multicolumn{2}{|c|}{3 Days } & \multicolumn{2}{|c|}{4 Days } & \multicolumn{2}{|c|}{5 Days } & \multicolumn{2}{|c|}{6 Days } & \multirow[t]{2}{*}{7 Days } \\
\hline & & & & & Mou & use $\mathrm{Nc}$ & & & & & \\
\hline & $1 \quad 2$ & $\begin{array}{ll}3 & 4\end{array}$ & 5 & 6 & 7 & 8 & 9 & 10 & 11 & 12 & 13 \\
\hline Brain & -0.7 & -3.5 & 4.23 & 5.23 & 6.74 & 6.74 & 7.74 & 8.5 & 8.4 & 8.74 & 0.0 \\
\hline Blood & -- & - & - & 1.74 & - & 1.74 & 0.5 & 2.62 & 3.74 & 3.23 & 4.5 \\
\hline Spleen & -- & - & $\leqq 1.5$ & $\leqq 1.5$ & $\leqq 1.5$ & $\leqq 1.5$ & $\leqq 2.5$ & $\leqq 2.5$ & 4.23 & 4.23 & 4.0 \\
\hline Liver & -- & - & - & - & - & - & $\leqq 1.5$ & $\leqq 1.5$ & 3.0 & $\supseteqq 4.5$ & 2.67 \\
\hline Kindneys & -- & -- & $\leqq 1.5$ & 0.7 & $\leqq 1.5$ & 2.74 & 1.74 & $\leqq 1.5$ & 3.74 & 3.5 & 5.0 \\
\hline Adr & -- & -- & $\leqq 1.5$ & $\leqq 1.5$ & $\leqq 2.5$ & 3.74 & $\leqq 3.5$ & $\leqq 3.5$ & 5.25 & 5.5 & 5.67 \\
\hline $\begin{array}{l}\text { Gl. Sub- } \\
\text { mandib. }\end{array}$ & -- & -- & $\leqq 1.5$ & $\leqq 1.5$ & $\leqq 1.5$ & $\leqq 1.5$ & 2.5 & 3.4 & 5.25 & 4.5 & 5.5 \\
\hline $\begin{array}{l}\text { Small } \\
\text { Intest. }\end{array}$ & -- & - & $\leqq 1.5$ & - & $\leqq 1.5$ & $\leqq 1.5$ & $\leqq 1.5$ & $\leqq 1.5$ & $\leqq 2.5$ & $\leqq 2.5$ & 2.67 \\
\hline $\begin{array}{l}\text { Large } \\
\text { Intest. }\end{array}$ & - & - & - & - & $\leqq 1.5$ & $\leqq 1.5$ & $\leqq 2.5$ & $\leqq 2.5$ & 2.74 & $\leqq 2.5$ & 3.5 \\
\hline $\begin{array}{l}\text { Ly. Gl. } \\
\text { Mesente. }\end{array}$ & -- & -- & - & - & $\leqq 1.5$ & 2.23 & $: \leqq 2.5$ & $\leqq 2.5$ & 5.23 & $\geqq 5.5$ & $\supseteqq 5.5$ \\
\hline $\begin{array}{l}\text { Muscle } \\
\text { Urine }\end{array}$ & -- & - & - & - & - & - & - & - & $\supseteqq 1.5$ & $\supseteqq 1.5$ & $\begin{array}{c}\supseteqq 1.5 \\
1.33\end{array}$ \\
\hline
\end{tabular}

All figures indicate the logarithm of $L D_{50}$ endpoint dilution.

Dashes indicates " no virus detected".

Blankes indicate " not tested".

?: indicates the $L D_{50}$ of the virus was not obtainable due to accident.

Tr: indicates some of the four mice inoculated with the undiluted blood died.

$>$ : indicates the titer of virus is higher than.

$<$ : indicates the titer of virus is lower than.

$\leqq$ : indicates the titer of virus is equal to.

Numerators indicate the number of mice infected.

Denominatores indicate the number of mice used. 
Moreover, intracerebral injection with Negishi strain was made to learn the susceptibility of various organs of mice, and found that the virus had multiplied in brain and had been transfered to various organs. This finding was identical with that of Nakayama or St. Louis strains, though the titer of virus in blood was higher.

By oral administration, Russian spring summer encephalitis virus easily infected mice, therefore, it should possess similar biological character to Negishi strain. Under this expectation, various organs of mouse infected with Russian spring summer encephalitis virus were examined. The results are shown in Table 6 . It appeared that the virus was present in blood earlier than in brain following the infection. On making comparison as

Table 6

Distribution of Russian Spring Summer Encephalitis Virus in Susceptible Mice Following Intranasal Instillation.

$(10 \mathrm{x}, 0.05$ ce. $)$

i. c. $\mathrm{LD}_{55}=9.0$

\begin{tabular}{|c|c|c|c|c|c|c|c|c|c|c|c|c|}
\hline \multirow{4}{*}{ Organs } & \multicolumn{12}{|c|}{ Days Elapsed After Inoculation. } \\
\hline & \multicolumn{2}{|c|}{1 Day } & \multicolumn{2}{|c|}{2 Days } & \multicolumn{2}{|c|}{3 Days } & \multicolumn{2}{|c|}{4 Days } & \multicolumn{2}{|c|}{5 Days } & 6 Days & \multirow[t]{2}{*}{7 Days } \\
\hline & \multicolumn{11}{|c|}{ Mouse No. } & \\
\hline & 1 & 2 & 3 & 4 & 5 & 6 & 7 & & 9 & 10 & $\begin{array}{ll}11 & 12\end{array}$ & 13 \\
\hline Brain & - & - & & $5 / 5$ & & $3 / 4$ & $5 / 5$ & & 6.0 & 6.5 & 8.08 .0 & 9.0 \\
\hline Blood & $4 / 4$ & - & $5 / 5$ & $5 / 5$ & & $5 / 5$ & $5 / 5$ & & 2.0 & 2.5 & $2.0 \quad 3.0$ & 3.67 \\
\hline Spleen & - & - & $1 / 5$ & $4 / 5$ & & $5 / 5$ & $5 / 5$ & & 3.5 & 3.5 & $3.67 ?$ & 5.0 \\
\hline $\begin{array}{c}\text { Gr. Sub- } \\
\text { mandib. }\end{array}$ & 一 & - & & $1 / 4$ & & $5 / 5$ & $5 / 5$ & & & & & \\
\hline Kidneys & - & - & & - & & $5 / 5$ & $2 / 5$ & & & & & \\
\hline $\begin{array}{l}\text { Ly. Gl. } \\
\text { Mesente. }\end{array}$ & - & - & $1 / 5$ & - & $5 / 5$ & $5 / 5$ & $5 / 5$ & & & & & \\
\hline Adrenals & 一 & 一 & & - & - & - & $4 / 5$ & & 2.5 & 3.67 & 4.674 .5 & 6.5 \\
\hline
\end{tabular}

All figures indicate the logarithm of $\mathrm{LD}_{50}$ endpoint dilution.

Dashes indicates " no virus detected".

Blankes indicate " not tested".

?: indicates the $\mathrm{LD}_{50}$ of the virus was not obtainable due to accident.

Tr.: indicates some of the four mice inoculated with the undiluted blood died.

$>$ : indicates the titer of virus is higher than.

$<$ : indicates the titer of virus is lower than.

$=$ : indicates the titer of virus is equal to.

Numerators indicate the number of mice infected.

Denominatores indicate the number of mice used. 
to the appearance of virus in blood, Russian spring summer encephalitis virus was found to appear in blood stream earlier than the virus of Negishi strain. Since Negishi strain had been passed through only but a few mouse brains and was regarded as relatively fresh from isolation, in view of the findings obtained from the experiments mentioned in the preceding made with newly isolated strains, Negishi strain was expected to be less rapid to reach the brains of mice than the strains of fixed virus. Contrary to the expectation, Russian spring sunmer encephalitis virus, which is a fixed virus, showed an earlier appearance in the blood stream with a higher concentration than Negishi strain, thus, these two strains are considered encephalitis viruses of different biological characters (Table 7).

Table 7

Distribution of Negishi and Russian Spring Summer (Western Type) Encephalitis Viruses in Susceptible Mice Following Intranasal Instillation.

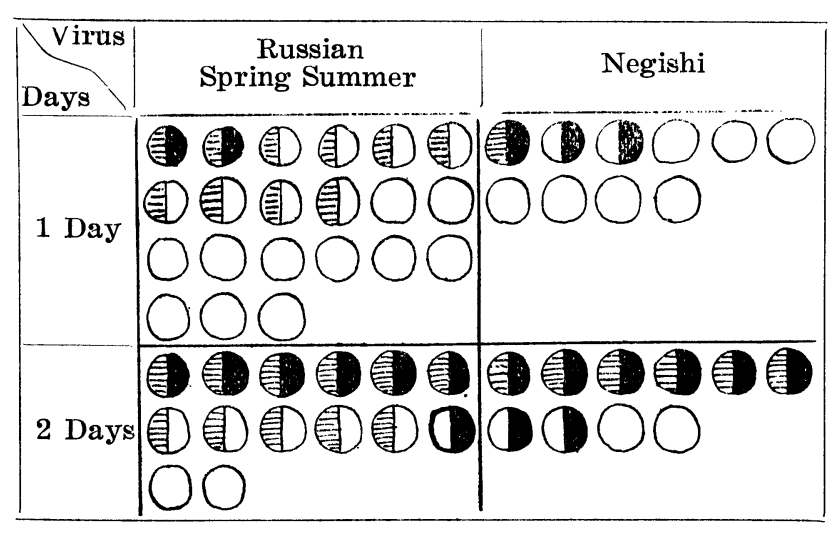

Note :

indicates one mouse in which the virus was not proved present in brain tissue and blood.

indicates one mouse in which the virus was proved present only in brain tissue.

(n) indicates one mouse in which the virus was proved present only in blood.

indicates one mouse in which the virus was proved in brain tissue as well as in blood.

2. Intravenous inoculation.

The results are shown in Tables 8 to 13 . With elapse of time after inoculation, 5 hours, 24 hours and so on, the virus of Nakayama strain intravenousely inocula:ed into mice became difficult to prove its presence in blood as if it was absorbed into the body of animal (Table 8). Similar 
tendency was observed with St. Louis virus. When the virus was found to present in blood, its titer was very low, and even such occurrence was ex remely rare.

Table 8

Distribution of Jap. B Encephalitis Virus (Nakayama Strain) in Susceptible Mice Following Intravenous Inoculation.

$(60 \mathrm{x}, 0.02$ ce. $)$

i. c. $\mathrm{LD}_{50}=7.5$

\begin{tabular}{|c|c|c|c|c|c|c|c|c|c|c|c|c|c|c|c|}
\hline \multirow{4}{*}{ Organs } & \multicolumn{15}{|c|}{ Days Elapsed After Inoculation. } \\
\hline & \multicolumn{2}{|c|}{ Imm. } & \multicolumn{2}{|c|}{$5 \mathrm{hrs}$} & \multicolumn{2}{|c|}{1 Day } & \multicolumn{2}{|c|}{2 Days } & \multicolumn{2}{|c|}{3 Days } & \multirow{2}{*}{\multicolumn{2}{|c|}{4 Days }} & \multirow[t]{2}{*}{\begin{tabular}{|c|}
5 \\
Days \\
\end{tabular}} & \multicolumn{2}{|c|}{6 Days } \\
\hline & \multicolumn{12}{|c|}{ Mouse No. } & & & \\
\hline & 1 & 2 & 3 & 4 & 5 & 6 & 7 & 8 & 9 & 10 & 11 & 12 & 1314 & $15 \quad 16$ & 16 \\
\hline Brain & $\mathrm{Ca} 0.67$ & $7-$ & - & - & - & $\mathrm{Ca} 1.2$ & $\geqslant 2$. & 5 & & $\supseteqq 3.5$ & $\geqslant 4.5$ & $\geqq 4$. & $5 \mid--$ & Ca7.77 & 6.5 \\
\hline Blood & $\geqslant 2.5$ & $\begin{array}{c}\mathrm{Ca} \\
2.0\end{array}$ & $\begin{array}{l}\mathrm{Ca} \\
1.33\end{array}$ & $\begin{array}{c}\mathrm{Ca} \\
0.67\end{array}$ & $\operatorname{Tr}$ & $\operatorname{Tr}$ & - & - & ? & - & - & - & -- & - & - \\
\hline Spleen & $\triangleq 3.5$ & $\begin{array}{c}\mathrm{Ca} \\
3.33\end{array}$ & $\supseteqq 3.5$ & - & 1.5 & - & - & - & - & - & 0.67 & 1.0 & -0.67 & - & - \\
\hline
\end{tabular}

All figures indicate the logarithm of $\mathrm{LD}_{50}$ endpoint dilution.

Dashes indicates " no virus detected".

Blankes indicate " not tested".

?: indicates the $\mathrm{LD}_{50}$ of the virus was not obtainable due to accident.

Tr: indicates some of the four mice inoculated with the undiluted blood died.

$>$ : indicates the titer of virus is higher than.

$<$ : indicates the titer of virus is lower than.

$=$ : indicates the titer of virus is equal to.

Numerators indicate the number of mice infected.

Denominatores indicate the number of mice used.

The results obtained with $\mathrm{K}-11$ strain were practically the same. The titer of virus on the first day was equal or even higher than that immediately after the inoculation, but afterwards, the virus present in blood was practically none (Table 9). In order to explain further the multiplication of virus in blood on the first day in detail, five mice were used separately. The results are shown in Fig. 1. Virus present in blood 6 hours after the inoculation was almost negligible, then it went on increasing and by 24 hours, the titer of virus became almost equal to what was observed at the time of inoculation and thereafter, the virus in blood decreased. 
Table 9

Distribution of Jap. B Encephalitis virus (K-11 Strain, 13th Pass.) in Susceptible Mice Following Intravenous Inoculation.

$$
(1,000 \times, 0.05 \text { cc. })
$$

i. c. $\mathrm{LD}_{50}=7.33$

\begin{tabular}{|c|c|c|c|c|c|c|c|c|c|c|c|c|c|c|}
\hline \multirow{4}{*}{ Organs } & \multicolumn{14}{|c|}{ Days Elapsed After Inoculation. } \\
\hline & \multicolumn{2}{|c|}{ Imm. } & \multicolumn{2}{|c|}{$5 \mathrm{hrs}$} & \multicolumn{2}{|c|}{1 Day } & \multicolumn{2}{|c|}{2 Days } & \multicolumn{2}{|c|}{3 Days } & \multicolumn{2}{|c|}{6 Days } & 7 Days & \multirow[t]{2}{*}{8 Days } \\
\hline & \multicolumn{13}{|c|}{ Mouse No. } & \\
\hline & 1 & 2 & 3 & 4 & 5 & 6 & 7 & 8 & 9 & 10 & 11 & 12 & 1314 & $\begin{array}{ll}15 & 16\end{array}$ \\
\hline Brain & - & - & - & - & - & - & - & - & 1.33 & 3.33 & - & - & -5.67 & - \\
\hline Blood & 1.5 & 0.5 & $\operatorname{Tr}$ & 1.33 & Ca1.33 & $\supseteqq 1.5$ & $\operatorname{Tr}$ & - & - & - & - & - & - & -- \\
\hline Spleen & - & - & 1.77 & 2.0 & - & 1.0 & 1.33 & - & - & 3.33 & - & - & - & -0.67 \\
\hline
\end{tabular}

All figures indicate the logarithm of $\mathrm{L}_{50}$ endpoint dilution.

Dashes indicates " no virus detected".

Blankes indicate " not tested".

?: indicates the $\mathrm{LD}_{5}$, of the virus was not obtainable due to accident.

Tr: indicates some of the four mice inoculated with the undiluted blood died.

$>$ : indicates the titer of virus is higher than.

$<$ : indicates the titer of virus is lower than.

$=$ : indicates the titer of virus is equal to.

Numerators indicate the number of mice infected.

Denominatores indicate the number of mice used.

Similar results were obtained with Komagome strain of the 8th passage, which was inoculated in a different concentration. Presence of the virus was scarcely proved in blood two days after the inoculation (Table 10 . As, in these experiments, details of virus concentration in blood before 24 hours were not clear, the following experiments were carried out. In the same manner, experiments were carried out with Fujimaki strain of the 3rd passage. The results showed decrease of the virus in the blood once 6 hours later, but $24 \mathrm{~h}$ urs later, the virus increased a little, and thereafter the virus was proved present in blood (Table 11). It was repo:ted by J.L. Peck \& A.B. S $\lrcorner b^{(18)}$ that in their experiments made with St. Louis virus inoculating mice intravenously, they found higher titers of the virus present in lungs than in blood. In the above experiments made with Fuj maki strain, therefore, lungs were also examined at the end of 6 hours after the in culation expecting to detect precense of the virus likewise but failed in obtainino : ny particular ' bservati ns. 


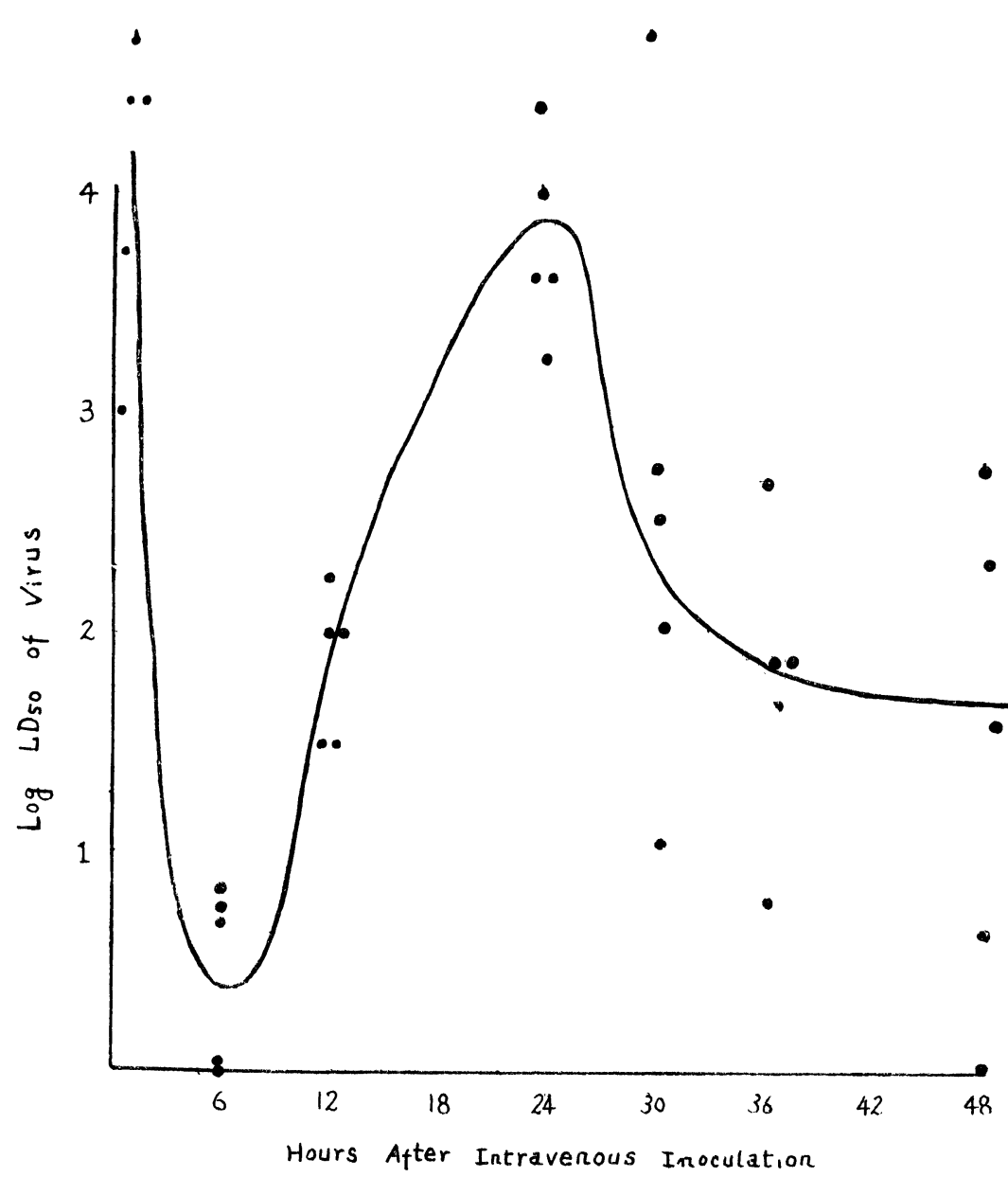

Fig 1

Recovery of Jap. B Encephalitis Virus ( $K-11$ Strain, 16th Passage) from the Mouse Blood after Intravenous Inoculation.

With Negishi strain, though there was a drop in the b'ord titer if virus for a fairly prolonged period after the inocuation, it maintained re'ative'y higher titers in blood until the terminal stage of the animals when compared with those of Japanese B encephalitis vi us and St L uis virus. In this point, the biological character of Negishi st ain is c'early different fiom either of Japanese B and St. Louis encephalitis virus (Table 12). Though not mentioned in this paper, 2 series of separate experiments were made with Negishi strain in a dilution of $10^{-4}$. In the first series, 
Table 10

Distribution of Jap. B Encephalitis Virus (Komagome Strain, 8th Pass.) in Susceptible Mice Following Intravenous Inoculation.

$(30 \times, 0.3 \mathrm{cc}$.

i. c. $\mathrm{LD}_{50}=7.5$

\begin{tabular}{|c|c|c|c|c|c|c|c|c|c|c|c|c|c|c|}
\hline \multirow{4}{*}{ Organs } & \multicolumn{14}{|c|}{ Days Elapsed After Inoculation. } \\
\hline & Imm. & $5 \mathrm{~h}$ & hrs & $1 \mathrm{Da}$ & & $2 \mathrm{Dr}$ & ays & $3 \mathrm{I}$ & Days & $4 \mathrm{D}$ & Days & $5 \mathrm{D}$ & Pays & 6 Days \\
\hline & \multicolumn{14}{|c|}{ Mouse No. } \\
\hline & 12 & 3 & 4 & 5 & & 7 & 8 & 9 & 10 & 11 & 12 & 13 & 14 & $15 \quad 16$ \\
\hline Brain & - & - & - & - & & 1.5 & - & 2.23 & $\supseteqq 3.5$ & $\geqslant 4.5$ & 3.3 & 7.0 & - & 4.67 \\
\hline Blood & $-\supseteqq 1.5$ & $\supseteqq 1.5$ & - & $0.5,0$. & & $\operatorname{Tr}$ & - & - & - & - & - & $\operatorname{Tr}$ & - & - \\
\hline Spleen & $-\supseteqq 2.5$ & $2.33 \geqq$ & $\geqslant 2.5$ & $\mathrm{Ca} 1.5$ & & $?$ & - & - & - & - & 0.6 & - & - & - \\
\hline
\end{tabular}

All figures indicate the logarithm of $\mathrm{LD}_{60}$ endpoint dilution.

Dashes indicates " no virus detected".

Blankes indicate " not tested".

?: indicates the $\mathrm{LD}_{50}$ of the virus was not obtainable due to accident.

Tr: indicates some of the four mice inoculated with the undiluted blood died.

$>$ : indicates the titer of virus is higher than.

$<$ : indicates the titer of virus is lower than.

$=$ : indicates the titer of virus is equal to.

Numerators indicate the number of mice infected.

Denominatores indicate the number of mice used.

Table 11

Distribution of Jap. B Encephalitis Virus (Fujimaki Strain, 3rd Pass.) in Susceptible Mice Following Intravenous Inoculation.

$$
(50 \times, 0.3 \text { cc.) }
$$

i. c. $L D_{50}=8.5$

\begin{tabular}{|c|c|c|c|c|c|c|c|c|c|c|c|c|}
\hline \multirow{4}{*}{ Organs } & \multicolumn{12}{|c|}{ Days Elapsed After Inoculation. } \\
\hline & \multicolumn{2}{|c|}{ Imm. } & \multicolumn{2}{|c|}{$6 \mathrm{hrs}$} & \multicolumn{2}{|c|}{1 Day } & \multicolumn{2}{|c|}{2 Days } & \multirow[t]{2}{*}{3 Days } & \multirow[t]{2}{*}{5 Days } & \multirow[t]{2}{*}{\begin{tabular}{|c}
8 \\
Days
\end{tabular}} & \multirow[t]{2}{*}{$\begin{array}{c}10 \\
\text { Days }\end{array}$} \\
\hline & \multicolumn{8}{|c|}{ Mouse No. } & & & & \\
\hline & 1 & 2 & 3 & 4 & 5 & 6 & 7 & 8 & $\begin{array}{ll}9 & 10\end{array}$ & $11 \quad 12$ & 1314 & 1516 \\
\hline Brain & $\triangleq 2.5$ & 1.23 & - & - & - & 1.5 & 2.0 & Ca2.77 & $-\supseteqq 4.5$ & $-\geqq 6.5$ & & 7.33 \\
\hline Blood & $\geqslant 4.5$ & 3.5 & 0.67 & - & 1.67 & 2.5 & - & 0.5 & $-\operatorname{Tr}$ & -- & - & - \\
\hline $\begin{array}{l}\text { Lung } \\
\text { Testic- } \\
\text { le }\end{array}$ & 4.01. & $5 \sim 3.5$ & - & - & - & 2.33 & $31.5 \sim 2.5$ & $5 \quad 1.0$ & -1.0 & - & 1.23 & - \\
\hline
\end{tabular}

All figures indicate the logarithm of $\mathrm{LD}_{50}$ endpoint dilution.

Daches indicates " no virus detected".

Blankes indicate " not tested".

?: indicates the $L D_{50}$ of the virus was not obtainable due to accident. 
$\operatorname{Tr}$ : indicates some of the four mice inoculated with the undiluted blood died.

$>$ : indicates the titer of virus is higher than.

$<$ : indicates the titer of virus is lower than.

$=$ : indicates the titer of virus is equal to.

Numerators indicate the number of mice infected.

Denominatores indicate the number of mice used.

no proof was obtainable as to the presence of the virus in brain, blood and spleen, while in the other series the virus was found to be present in blood $\left(\mathrm{LD}_{5 \mathrm{~J}}=1.77\right)$ and spleen $\left(\mathrm{LD}_{50}=1.5\right)$ of one mouse but not in brain.

Table 12

Distribution of Negishi Encephalitis Virus in Susceptible

Mice Following Intravenous Inoculation.

$$
(10,000 \times, 0.5 \text { cc. })
$$

i. c. $\mathrm{LD}_{50}=9.0$

\begin{tabular}{|c|c|c|c|c|c|c|c|c|c|c|c|c|c|c|}
\hline \multirow{4}{*}{$\begin{array}{c}\text { Or- } \\
\text { gans }\end{array}$} & \multicolumn{14}{|c|}{ Days Elapsed After Inoculation. } \\
\hline & $\operatorname{Imm}$ & & 5 hrs & & 1 Day & & Day & & \begin{tabular}{|c|}
3 \\
Days
\end{tabular} & $4 \mathrm{Da}$ & ays & 5 Days & 6 Days & 7 Days \\
\hline & \multicolumn{14}{|c|}{ Mouse No. } \\
\hline & 1 & 2 & 3 & 1: 5 & 5 & 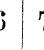 & 78 & & 10 & 11 & 12 & 1314 & 1516 & $\begin{array}{ll}17 & 18\end{array}$ \\
\hline rain & -1 & & - & & - & -1 & - & & -- & $\supseteq 3.5$ & 1.3 & $3.0 \leqq 2.5$ & $\leqq 4.5 \leqq 4.5$ & $0.00 \leqq$ \\
\hline Blood & 2.23 & 1.01 & 1.330 .4 & & 670.6 & & 671. & & $\mathbf{r}-$ & - & 1.38 & $1.0 \quad 1.67$ & $\leqq 0.5 \leqq 0.5$ & $4.0 \leqq 0$ \\
\hline $\begin{array}{l}\text { Sp- } \\
\text { leen }\end{array}$ & 1.671. & $1.23{ }_{0}^{0}$ & $\begin{array}{l}\mathrm{Ca} \\
0.67^{1}\end{array}$ & & & & .51. & & $?-$ & - & 1.5 & $2.0 \quad 3.5$ & $4.0 \quad 1.5$ & $3.33-$ \\
\hline
\end{tabular}

All figures indicate the logalithm of $\mathrm{LD}_{50}$ endpoint dilution.

Dashes indicates "no virus detected".

Blankes indicate " not tested".

?: indicates the $\mathrm{LD}_{50}$ of the virus was not obtainable due to accident.

Tr: indicates some of the four mice inoculated with the undiluted blood died.

$>$ : indicates the titer of virus is higher than.

$<$ : indicates the titer of virus is lower than.

$=$ : Indicates the titer of virus is equal to.

Numerators indicate the number of mice infected.

Denominatores indicate the number of mice used.

With Russian spring summer encephalitis virus in a dilution of $10^{-4}$, the blood titer of virus was higher than that of Negishi strain, and in an early period after infection, it appeared as if the virus multiplied in blood. Experiments were carried out again with a $10^{-5}$ dilution of the virus. The results showed that the blood titer of virus on early days after the 
inoculation was equal to or higher than that examined at the time of inoculation, prior to the appearance in brain (Table 13).

Table 13

Distribution of Russian Spring Summer Encephalitis Virus (Western Type) in Susceptible Mice Following Intravenous

Inoculation. $(100,000 \times, 0.5 \mathrm{cc}$.

i. c. $\mathrm{LD}_{50}=9.0$

\begin{tabular}{|c|c|c|c|c|c|c|c|c|c|c|c|c|c|c|c|c|}
\hline \multirow{4}{*}{$\begin{array}{l}\text { Or- } \\
\text { gans }\end{array}$} & \multicolumn{16}{|c|}{ Days Elapsed After Inoculation. } \\
\hline & \multicolumn{3}{|c|}{ Imm. $5 \mathrm{hrs}$. } & $1 \mathrm{Da}$ & \multicolumn{3}{|c|}{2 Days } & $3 \mathrm{D}$ & ays & $4 \mathrm{I}$ & Days & $5 \mathrm{D}$ & Days & $6 \mathrm{Da}$ & ays & 7 Days \\
\hline & \multicolumn{16}{|c|}{ Mouse No. } \\
\hline & 12 & 3 & 4 & 5 & & 7 & 8 & 9 & 10 & 11 & 12 & 13 & 14 & 15 & 16 & $\begin{array}{ll}17 & 18\end{array}$ \\
\hline rain & -- & - & - & - & & - & & - & - & & -1 & & 2.5 & 2.67 & $2.6^{\prime}$ & $\leqq 4.5 \quad 7.6$ \\
\hline Blood & 0.50 .77 & - & - & $\operatorname{Tr} 0$ & & .672 & & 1.33 & 0.6 & 71.0 & 1.23 & & 2.5 & $\triangleq 3.5$ & & 1.51 .5 \\
\hline $\begin{array}{l}\text { Sp- } \\
\text { leen }\end{array}$ & 1.01 .0 & - & - & 2.02 & & -2 & & $-\mathrm{C}$ & Za3.3 & & 73.5 & & 4.33 & Ca3.67 & 673. & 1.3 \\
\hline
\end{tabular}

All figures indicate the logarithm of $\mathrm{LD}_{50}$ endpoint dilution.

Dashes indicates " no virus detected".

Blankes indicate " not tested".

?: indicates the $\mathrm{LD}_{50}$ of the virus was not obtainable due to accident.

$\mathrm{Tr}$ : indicates some of the four mice inoculated with the undiluted blood died.

$>$ : indicates the titer of virus is higher than.

$<$ : indicates the titer of virus is lower than.

$=$ : indicates the titer of virus is equal to.

Numerators indicate the number of mice infected.

Denominatores indicate the number of mice used.

3. Intratesticular inoculation.

a. Determination of $\mathrm{LD}_{50}$.

Various strains of encephalitis virus such as Nakaya 1 a, Fujimaki, Oikawa, Negishi and Russian spring summer encephalitis, were used in the present experiments. Period of observation was 21 days. The results showed that there was a difference in their infectivity to mice. Fujimaki and Oikawa strains, which have been subjected to only but a few mouse brain passages, can not be more infectious than Fujimaki strain of 55th mouse brain passage. Thus, it appears that the virus becomes gradually more and more infectious as the brain passage is repeated. While the $L_{50}$ of Nakayama strain, which is fixed virus, is approximately 1.33 , that of Negishi strain is 4.42 and that of Russian spring summer encephalitis virus is 6.33 . 
b. Possibility of subsequent passage.

E.H. Lennette \& M.G. Smith had reported that the propagation of St. Louis and Japanese B encephalitis viruses in mouse testicle was possible ${ }^{(36)}$. Experiments made with Nakayama and Negishi strains, showed that subsequent passages were practicable. The passages were made at an interval of 7 to 10 days with a 5 per cent emulsion of mouse testicles. On each passage, virus in testicle and brain was titrated. The virus concentration in testicle was 5.5 to 7.5 in terms of $L_{50}$. Propagation of the virus of Negishi strain in mouse testicle was discontinued on the 32nd generation.

c. Recovery of encephalitis virus from mouse testicle.

As the propagation of encephalitis virus in mouse testicle was found practicable, the duration of presence of virus in mouse testicle was examined with Nakayama and Negishi strains. Higher titers of the virus in mouse testicle than those at the time of inoculation were observed from 7 to 10 days after the inoculation. Doses of the virus inoculated in these experiments, were approximately $0.03 \mathrm{cc}$ of Negishi strain in a dilution of $10^{-4}$ and approximately $0.03 \mathrm{cc}$ of Nakayama strain in a dilution of $10^{-1}$, which were considered sufficient to infect mice. Table 14 shows the results obtained with Negishi strain.

When mouse testicles were inoculated with Nakayama strain in a dilution of $10^{-4}$, all mice inoculated did survive. The experiment made with this dilution showed a definite multiplication of the virus in testicle during 7 to 10 days after the inoculation, decrease thereafter, and disappearance by the 21st day. During the period of above observation, the virus was not found in brain (Table 15). In the case of Nakayama strain, the virus was found to be present in blood for about 2 days following the inoculation, whereas in the case of Negishi strain, the virus was found to be present throughout the observation period though lower in titer than what was observed at the time of inoculation.

d. Experiments made on rabbits.

Distribution of virus in rabbits following intratesticular inoculation with Nakayama, Negishi and Russian spring summer encephalitis viruses was examined. These viruses were found not to multiply in rabbit testicles. Neutralizing antibody in the blood of the above rabbits were not examined, but since none of them multiplied in their testicles, it is not due to the 
neutralizing antibody in the blood that they did not multiply in the testicles.

Table 14

Distribution of Negishi Encephalitis Virus in Susceptible

Mice Following Intratesticular Inoculation.

$(1,000 \times .0 .03 \mathrm{cc}$.

i. c. $\mathrm{LD}_{50}=8.33$

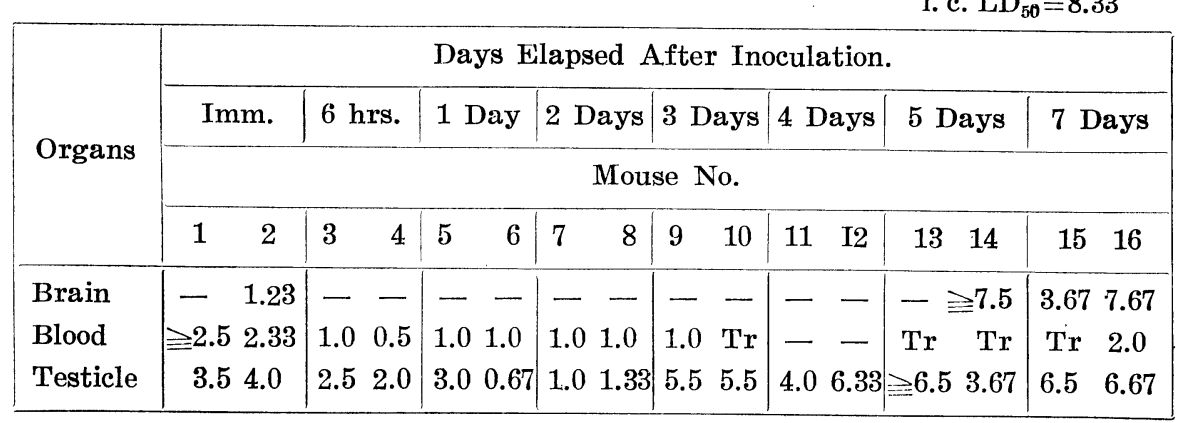

All figures indicate the logarithm of $\mathrm{LD}_{50}$ endpoint dilution.

Dashes indicates " no virus detected".

Blankes indicate " not tested".

?: indicates the $\mathrm{LD}_{50}$ of the virus was not obtainable due to accident.

Tr: indicates some of the four mice inoculated with the undiluted blood died.

$>$ : indicates the titer of virus is higher than.

$<$ : indicates the titer of virus is lower than.

$=$ : indicates the titer of virus is equal to.

Numerators indicate the number of mice infected.

Denominatores indicate the number of mice used.

e. Virus titer in mouse testicle following the inoculation made through various routes other than intratesticular inoculation.

The virus inoculated directly into mouse testicle was found to multiply in it, but when inoculated otherwise namely, intranasally or intravenousely the virus was found not to multiply in testicle Table 3, 411 .

Thus, it is inferable that the virus does not multiply in testicle before it did multiply in brain. Experiments were undertaken, therefore, in order to know the titer of virus in testicle of the mouse in its terminal stage infecting mice with the virus of Nakayama strain. Virus titers in the testicles were very low denying the presumption of virus multiplication in testicle. Thus it was considered important to provide such a condition as mechanical injuries to testicle tissue caused by injection etc. to enable the virus multiplying in mouse testicle. In view of the above findings, 
Table 15

Distribution of Jap. B Encephalitis Virus (Nakayama Strain) in Susceptible Mice Following Intratesticular Inoculation.

$$
(10,000 \times, 0.03 \text { cc. })
$$

i. c. $\mathrm{LD}_{50}=8.33$

\begin{tabular}{|c|c|c|c|c|c|c|c|c|c|c|c|c|c|c|c|c|c|}
\hline \multirow{4}{*}{ Organs } & \multicolumn{17}{|c|}{ Days Elapsed After Inoculation. } \\
\hline & Imm. & $6 \mathrm{hr}$ & & $1 \mathrm{Da}$ & & $2 \mathrm{Da}$ & ays & $3 \mathrm{D}$ & ays & $6 \mathrm{D}$ & ays & & Days & $14 \mathrm{I}$ & Days & $\mid \begin{array}{c}21 \\
\text { Day }\end{array}$ & \\
\hline & \multicolumn{17}{|c|}{ Mouse No. } \\
\hline & 1 & 3 & 4 & 5 & 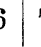 & 7 & 8 & 9 & 10 & 11 & 12 & 13 & 14 & 15 & 16 & 17 & 18 \\
\hline Brain & - & - & - & - - & & - & - & - & - & - & 一 & - & - & - & - & - & \\
\hline Blood & $0.5-$ & & - & 0.5 & & $\operatorname{Tr}$ & - & - & - & - & - & - & - & - & - & - & \\
\hline Testicle & 1.52 .6 & 2.45 & 2.0 & 3.04 & & @4.5 & 2.5 & 4.67 & 3.0 & $\supseteqq 7.5$ & 5.6 & 77.0 & $\geqq 7$. & 3.67 & 6.0 & & - \\
\hline
\end{tabular}

All figures indicates the logarithm of $\mathrm{LD}_{50}$ endopoint dilution. Dashes indicates " no virus detected".

Blankes indicate " not tested".

?: indicates the $\mathrm{LD}_{50}$ of the virus was not obtainable due to accident.

Tr: indicates some of the four mice inoculated with the undiluted blood died.

$>$ : indicates the titer of virus is higher than.

$<$ : indicates the titer of virus is lower than.

$=$ : indicates the titer of virus is equal to.

Numerators indicate the number of mice infected.

Denominatores indicate the number of mice used.

the affinity of Nakayama strain to mouse testicle may be weaker than that to adrenal. Such experiments with Negishi and Russian spring summer encephalitis viruses were not carried out in view of the results obtained from inoculations made through various routes other than intratesticular inoculation, but it might be concluded that the multiplication of these viruses in the tissues of mouse testicle was not observable with Nakayama strain.

\section{DiscUsSion}

Experiments were made with various strains of encephalitis virus through various routes of infection, intranasal, intravenous and intratesticular inoculations, and studies were made on the affinity of those viruses to various organs of mouse. On the basis of the results obtained, it can be said that the difference in the affinity of those encephalitis viruses to 
various organs is the difference in the grade of their affinity to blood. But the affinity to central nervous system is strongest in any virus of any generation.

Regarding to the difference in the affinity of those strains of encephalitis virus to various organs of animals, especially to blood, R. Kobayashi ${ }^{(16)}$ reported that Japanese encephalitis virus was most infectious to mice and it caused 100 per cent mortality of the experimental infection and it was relatively easily found present in blood, while detection of the virus in the blood of monkey was difficult and in the case of human body, it was still more difficult. During the course of isolation of the virus from the encephalitis cases in summer, this kind of difficulty has always been encountered.

There is a difference also in the affinity to the tissues of animal infected with encephalitis viruses. R. Kobayashi described that there were many grades in infectivity when infected materials obtained from human were inoculated to mouse brain or the emulsion of infected mouse brain was inoculated to monkey brain, thus such difference in the affinity may be due to the difference in the pathogenicity of the virus contained in the inoculum, or due to the difference in its concentration ${ }^{(19)}$.

Experiments described herein showed the results indicating differences between those made with fresh virus (with less mouse brain passages) and those with fixed virus (with many mouse brain passages) inoculated through various routes. With Nakayama and St. Louis encepharitis viruses, it was very difficult to find the presence of virus in blood in an early period after the infection made intranasally, but with a fresh virus it was relatively easy though low in titer to detect the presence of virus before the virus was found in brain. Such appearance of virus in blood may be more frequent with fresh strains than with Nakayama and St. Louis strains.

L. T. Webster showed, through experiments made with various routes of inoculation (intraperitoneal, subcutaneous and intranasal inoculations), that Japanese encephalitis virus was found in blood earlier than St. Louis encephalitis virus. In other words, the virus was found with strong affinity to blood and found easily infectious to sheep. A similar results was found in the case of louping-ill virus, but serologically they were different ${ }^{(20)}$. Results of the experiments made by inoculating virus through intranasal route by $R$. Kawamura showed that Japanese B encephalitis 
virus had a greater tendency to enter blood stream in an early period of the infection ${ }^{(21)}$. R. Kobayashi described that there was a difference between the epidemic of 1936 and that of 1939 in the appearance of virus in blood stream when examined by nasal instillation ${ }^{(22)}$.

These results as mentioned above, may be regarded as biological difference existing between fresh and fixed viruses. As to the reasons why, it has been considered that nasal mucosa is not suitable for harboring virus (or virus may pass through nasal mucosa immediately), or the presence of virus is not proved in the nasal mucosa, as had already been explained by R. Kawamura(23) and J.L. Peck \& A.B. Sabin ${ }^{(24)}$. R. Kobayashi described that it appeared as if a portion of the virus reached brain through bulb nerve and another entered blood stream from nasal mucosa through lymph ${ }^{(25)}$. In other words, one part of the virus, which has passed through nasal mucosa, may enter blood stream, and another may reach olfactory bulb through olfactory nerve. Thus, it may be considered that the virus which has less affinity to mouse brain tissue takes time in reach ing to olfactory bulb through olfactory nerve, while another portion of the virus which entered blood stream is found earlier.

Biological difference existing between fresh and fixed viruses has already been recognized by many workers in U.S.A. ${ }^{(27)(28)(29)}$ and Germany ${ }^{(26)}$ on equine encephalomyelitis viruses (Eastern or western type). L.S. King, making experiments on mice with eastern equine encephalomyelitis virus through various routes of infection, found a biological difference between fresh and fixed viruses except when infected by intranasal, intraocular and intracerebral instillations, and reported that the fixed virus was found with very limitted power of invading the central nervous system along the axon of peripheral nerves even when injected directly into the nerve ${ }^{(\Sigma 9)}$.

In the experiments reported herein, the results of intratesticular inoculation showed a biological difference between fresh and fixed viruses, and it was more difficult to infect mice with fresh virus than with fixed virus. This may be due to the reason that the fresh virus was not yet adapted to the tissue of mouse brain. The fact that Fujimaki strain of the 55th passage has become more infectious to mouse is confirming the above explanation. Since substantial studies of such biological difference are impossible without considering the function and histological structures of testicle in living animal, only descriptions of the facts observed are made in the present paper. Also the difference in the affinity to blood 
among various strains was found by intravenous inoculation. Nakayama and St. Louis strains disappeared gradually from blood stream as if absorbed, and if it is present, the titer was so low that it could not be proved by intracerebral inoculation method.

With fresh virus, the blood titer was found nearly equal after 24 hours to what it was at the time of inoculation, and thereafter decreased. With Negishi strain, though lower than what it was at the time of inoculation, there was a considerable amount of virus present in blood stream. With Russian spring summer encephalitis virus, the blood titer was equal or even higher than what it was at the time of inoculation.

Increase and decrease of virus in blood stream, may be related to the problem of organs in which the virus can multiply, for the fact that the titer of fresh virus in blood stream after 24 hours, when inoculated intravenously, was nearly equal to what it was at the time of inoculation and thereafter decreased. This fact can be viewed from two stand-points, to regard it as multiplication of the virus in blood stream or temporary biological reaction.

The above facts should not be concluded that virus multiplies in blood stream. By the present methods of experiments, it is difficult to say that virus has multiplied in an organ, unless the blood titer of virus is equal or even higher than that at the time of inoculation and moreover to continue for a certain period of time.

Experiments carried out by J.R. Overman \& W.F. Friedewald with Semliki Forest virus on rabbits by intraocular inoculation showed that the virus decreased after inoculation, but by the elapse of time, multiplied gradually presenting even higher titers than that observed at the time of inoculation and remained for a few days. The author is of the opinion that, in those experiments, virus multiplied in eyes of the rabbits and that our experiments of intratesticular inoculation are of the same nature with different encephalitis viruses ${ }^{(24)}$. E.W. Hurst described that eastern equine encephalomyelitis virus inoculated into the muscles of guinea-pigs might multiply in blood or in vascular cells and in the reticuloendothelial system, for the reasons that the titer of virus in blood stream reached its highest on 2-3 days after the inoculation ${ }^{(30)}$.

As described above, there is a little biological difference in blood affinity between fresh and fixed strains of Japanese $B$ encephalitis virus and also between Negishi and Russian spring summer encephalitis viruses 
which are considered to circulate in blood stream in a relatively large amount.

Blood affinity of various strains of encephalitis viruses can be shown figuratively as follows:

Fixed virus. Fresh virus.

(Japanese $B$ encephalitis virus)

St. Louis encephalitis virus.

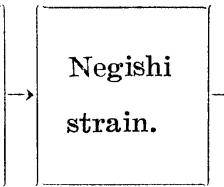

Russian spring summer encephalitis virus.

Further, including Negishi strain, those shown on the left side of the above figure, did not show experimental results to signify the multiplication of virus in blood stream, but Russian spring summer encephalitis virus shown on the right side showed relatively high titers signifying as if it multiplied in blood stream. Thus, the biological position of Negishi strain is considered lying between Nakayama strain which has a strong affinity to the tissue of mouse brain, and Russian spring summer strain which has a strong affinity to the tissue of mouse brain and also bloods. Moreover, it resembles to the biological character of louping-ill virus in the following points: that it is not infectious to rabbits and guineapigs $^{(9)(31)}$, that it is less infectious than Russian spring summer encephalitis virus to mice weighing $13 \mathrm{~g}$ when inoculated subcutaneously, and the infection occurres uncertainly ${ }^{(32)}$, that the same finding can be observed by intratesticular inoculation, that it appears in blood and brain in early days after inculation ${ }^{(33)}$, and that there have been laboratory infections ${ }^{(34)(35)}$.

\section{SUMMARY}

Experiments were made on the distribution of virus in various organs of mice infected with Negishi strain (isolated by K. Ando et al from an encephalitis case during the summer of 1948 in Tokyo) through various routes of inoculation and comparisons were made with Japanese B., St. Louis and Russian spring summer encephalitis viruses.

Results obtained showed that there was a graded difference in the affinity to various organs among the above mentioned strains of encephalitis viruses. In view of the biological characters shown by Negishi strain, it is considered that Negishi strain is standing biologically between Japanese B encephalitis virus which is not yet fully adapted to mouse brain and Russian spring summer encephalitis virus (western type). In- 
vestigations were made, in addition, on the affinity of various strains of encephalitis virus employing testicles as an organ other than central nervous system.

Further studies on Negishi strain are undergoing employing different methods of approach.

\section{ACKNOWLEDGEMENT}

Sincere thanks are due to Drs. R. Kobayashi and K. Ando who kindly directed the work. This work was supported by the fund arranged by the Ministry of Education for the Virus Chapter of Scientific Researches.

\section{REFERENCES}

1) Mitamura, T.: Epidemiological and experimental considerations of Japanese $B$ encephalitis made on various routes of infection. Tokyo Iji Shinshi, No. 3076, 825-832, 1938 (in Japanese).

2) Hammon, W. McD., Reeves W.C. and Izumi, E.M.: St. Louis encephalitis virus in the blood of experimentally inoculated fowls and mammals. J. Exp. Med., 83, 175-183, 1946.

3) Hammon, W. McD., Reeves, W.C., Brookman and Izumi E.M.: Isolation of the virus of the western equine and St. Louis encephalitis from Culex tarsalis mosquitoes. Science, 94, 328-330, 1941.

4) Kawamura R. et al.: Studies on encephalitis virus: On the development of Japanese B encephalitis. Tokyo Iji Shinshi, No. 3007, 3229-3237, 1936 (in Japanese).

5) Mitamura, T. et al.: Studies on the transmission of Japanese B encephalitis virus in mice. Tokyo Iji Shinshi, No. 3144-3145, 1966-1969, 1939 (in Japanese).

6) Webster, L.T. and Clow, A.D.: The limitted neurotropic character of the encephalitis virus (St. Louis type) in susceptible mice. J. Exp. Med., 63, 433-448, 1936.

7) Kobayashi, R. et al.: Studies on the virus of Japanese B encephalitis epidemic of Tokyo Yokohama area from 1936 to 1940. Nihon Igaku and Kenkohoken, No. 3270, 345-348, 1942 (in Japanese).

8) Takenouchi et al.: Studies on Japanese B encephalitis virus. Tokyo Iji Shinshi, No. 3075, 729-731, 1938 (in Japanese).

9) Ando, K. et al.: Studies on Japanese B encephalitis in the epidemic of 1948 . "Japanese B encephalitis". published by the Investigation \& Research committee for Japanese B Encephalitis. 35-56, 1950 (in Japanese).

10) Hironaka, N.: On the virus distribution in mice of Negishi strain isolated during the summer in 1948. Read at the joint Scientific Meeting held by the N.I.H. and the Insitute for Infectious Diseases, Tokyo University on June 23rd, 1948.

11) Reed. L.T. and Muench, H.: A simple method of estimating fifty per cent endopoints. Am. J. Hyg., 27, 493-497, 1938. 
12) Hironaka, N.: On the yolk buffered saline solution as a diluent for viruses. Kitasato Arch. Exp. Med., 23, 139-149, 1951.

13) Kimura, K.: On the intranasal instillation of mice with rabies virus. Saikingaku Zasshi, 583, 297-321, 1944 (in Japanese).

14) Kimura, K.: Supplementary studies on the distribution and affinity of Japanese B encephalitis virus in mice. Especially on the virus in submandiburaris and adrenals. Saikingaku Zasshi, 558, 388-411, 1942 (in Japanese).

15) Webster, L.T. and clow, A. B.: The limitted neurotropic character of the encephalitis virus (St. Louis type) in susceptible mice. J. Exp. Med., 63, 433-448, 1936.

16) Kobayashi, R. et al.: Studies on the Japanese B encephalitis virus in the epidemic of Tokyo and Yokohama in 1935 and 1936. Tokyo Iji Shinshi, No. 3004, 3004-3011, 1936 (in Japanese).

17) Takenouchi, et al.: Studies on the Japanese B encephalitis virus. Tokyo Iji Shinshi, No. 3079, 1087-1089, 1938 (in Japanese).

18) Peck, J.L. and Sabin, A.B.: Multiplication and spread of the virus of St. Louis encephalitis in mice with special emphasis on its fate in the alimentary tract. J. Exp. Med., 85, 647-662, 1947.

19) Kobayashi, R.: The comparison of concentration of the virus of Japanese encephalitis in the blood, cerebrospinal fluid and brain tissue of encephalitis patients and monkeys and mice infected with the virus. Kitasato Arch. Exp. Med., 18, 45-52, 1940.

20) Webster, L. T.: Japanese B encephalitis virus; its differentiation from St. Louis encephalitis virus and relationship to louping-ill virus. J. Exp. Med., 67, 609-618, 1938.

21) Kawamura, R. et al.: Studies concerning the virus of epidemic encephalitis, Japanese type. Kitasato Arch Exp. Med., 13, 281-323, 1936.

22. Kabayashi, R. et al.: Studies on Japanese B encephalitis virus in the epidemic of Tokyo and Yokohama in 1935, 1436, 1937, 1938 and 1939. Nihon Igaku and Kenko Hoken, No. 3209, 806-809, 1940 (in Japanese)

23) Kawamura, R. et al.: Studies on Japanese B encephalitis virus: Mechanism of the infection. Tokyo Iji Shinshi, No. 3007, 3229-3237, 1936 (in Japanese).

24) Overman, J.R. and Friedewald, W.F.: Multiplication of certain neurotropic viruses in the rabbit eye following intraocular inoculation. J. Exp. Med., 91. 39-51, 1950.

25) Kobayashi, R. et al.: Studies on Japanese $B$ encephalitis virus in the epidemic of Trkyo and Yokohama in 1935. Tokyo Iji Shinshi, No. 2968, 395-399, 1936 (in Japanese).

26) Traub, E.: Experimentelle Untersuchungen über einen durch Taubenpassage veränderten Virusstamm der amerikanischen Pferdenenzephalomyelitis. Zent. Bakt. Para. Infec., 143, 7-22, 1938-1939.

27) Sabin, A.B. and Olitsky, P.K.: Variations in pathways by which equine encephalomyelitis viruses invade the C.N.S. of mice and guinea pigs. Proc. Soc. Exp. Biol. \& Med., 38, 595-597, 1938a.

28) King, L.S.: Studies on eastern equine encephalomyelitis. III. Intraocular infection with fixed virus in the guinea pig. J. Exp. Med., 69, 691-703, 1939. 
29) King, L.S.: Studies on eastern equine encephalomyelities. IV. Infection in the mouse with fresh and fixed virus. J. Exp. Med., 71, 95-106, 1940.

30) Hurst, E.W.: Infection of the rhesus monkey (Macaca mulatta) and the guinea pig with the virus of equine encephalomyelitis. J. Path. Bact., 42, 271-302, 1936.

31) Alston, J.M. and Gibson, H.J.: A note on the experimental transmission of "louping-ill" to mice. Brit, J. Exp. Med., 12, 82-88, 1931.

32) Casals, J. and Webster, L.T.: Relationship of the virus of louping-ill in sheep and the virus of Russian spring summer encephalitis in man. J. Exp. Med., 79, 45-63, 1944.

33) Fite, G.L. and Webster, L.T.: Distribution of louping-ill in blood and brain of intranasally infected mice. Proc. Soc. Exp. Biol. \& Med., 31, 695-696, 1933-1934.

34) Kuratsuka et al.: On the laboratory infections with Negishi Strain. Read at the joint Scientific Meeting held by the N.I.H. and the Institute for Infectious Diseases, Tokyo University, on October 19, 1950.

35) Mitamura, T. et al.: A case of the laboratory infection with louping-ill virus. Tokyo Iji Shinshi, No. 3076, 774-775, 1938. (in Japanese).

36) Lennette, E. H. and Smith, M.G.: Propagation of the St. Louis and the Japanese $B$ encephalitis virus in mouse testicle. J. Inf. Dis., 66, 266-270, 1940 . 